\title{
Expression of Anthocyanin Biosynthesis Genes in the Skin of Peach and Nectarine Fruit
}

\author{
Tomomi Tsuda ${ }^{1}$ \\ Domestic Research Fellow, Japan Society for the Promotion of Science (JSPS) \\ Masami Yamaguchi, Chikako Honda, and Takaya Moriguchi \\ National Institute of Fruit Tree Science (NIFTS), 2-1 Fujimoto, Tsukuba, Ibaraki, 305-8605, Japan
}

\begin{abstract}
AdDitional IndeX words. Prunus persica, gene expression, coloration, fruit development, RNA, DNA
ABSTRACT. We used RNA blot analysis to examine the expression of six genes of the anthocyanin biosynthesis pathway in the flowers and fruit skins at three developmental stages of white and red peaches and a deep-red nectarine [Prunus persica $\left(\right.$ L. $_{\text {. }}$ Batch]. In the red peach 'Akatsuki' and the deep-red nectarine 'Flavortop', expression levels of anthocyanin biosynthesis genes were related to anthocyanin accumulation in the fruit skin; expression of all six genes dramatically increased at Stage III of fruit development, and anthocyanin concentration also increased at this stage. In the white peach 'Mochizuki', however, expression of the chalcone synthase gene $(\mathrm{CHS})$ and the dihydroflavonol 4-reductase gene $(D F R)$ was undetectable in Stage III, although the chalcone isomerase gene $(C H I)$, the flavanone 3-hydroxylase gene $(F 3 H)$, the anthocyanidin synthase gene $(A N S)$, and the UDP-glucose-flavonoid 3-O-glucosyltransferase gene (UFGT) were expressed. We occasionally found red pigment in the skin of 'Mochizuki' peach. In these red skin areas, both $C H S$ and $D F R$ were clearly expressed in Stage III. These results suggest that $C H S$ and $D F R$ are the key regulatory genes in the process of anthocyanin biosynthesis in mature red peach and nectarine.
\end{abstract}

The skin color of peach and nectarine fruit is an important factor in consumer appeal as well as in marketability. Anthocyanins are major pigments of fruit skins, and they are synthesized at an increasing rate during maturation, especially near maturity, reaching a maximum in the fully ripe fruit (Gross 1987). Six enzymes are generally involved in the anthocyanin biosynthesis pathway: chalcone synthase (CHS), chalcone isomerase (CHI), flavanone 3-hydroxylase (F3H), dihydroflavonol 4-reductase (DFR), anthocyanidin synthase (ANS), and UDP-glucose-flavonoid 3-O-glucosyltransferase (UFGT). The genes encoding these enzymes have been isolated and characterized in many plants (Holton and Cornish 1995). Some reports have described the relationship between the expression of these genes and anthocyanin accumulation (Boss et al., 1996a, 1996b; Honda et al., 2002; Kobayashi et al., 2001; Kondo et al., 2002; Li et al., 2001; Moyano et al., 1998). The key regulatory genes in the anthocyanin biosynthesis pathway vary with fruit species. In grape (Vitis vinifera L.), Boss et al. (1996a) and Kobayashi et al. (2001) demonstrated that UFGT was a key regulatory gene for anthocyanin accumulation. In strawberries (Fragaria $\times$ ananassa Duch.), the putative DFR gene plays a main role in anthocyanin biosynthesis during color development $(\mathrm{Li}$ et al., 2001; Moyano et al. 1998). Kondo et al. (2002) reported that, in apple [Malus sylvestris (L.) Mill. var. domestica (Borkh.) Mansf.] skin, expression of anthocyanin biosynthesis genes was positively related to anthocyanin concentration and that UFGT expression was closely related to anthocyanin expression at the ripening stage.

Received for publication 21 Oct. 2003. Accepted for publication 14 May 2004. The authors thank Shozo Kobayashi, Hiroko Hayama, Toshiya Yamamoto, Masayuki Kita, Chungen $\mathrm{Hu}$, and Zilian Zheng of the National Institute of Fruit Tree Science (NIFTS) for their technical advice. We also thank Yoshinori Ueda and Megumi Ishimaru of Osaka Prefecture Univ., Tadashi Baba of Tokyo Univ. of Agriculture, and Nobuko Mase of NIFTS for their helpful suggestions on earlier drafts.

${ }^{1}$ To whom reprint requests should be addressed: e-mail tomomi-t@ya2.so-net. ne.jp
An understanding of the regulatory mechanisms of anthocyanin biosynthesis in peach skin will help efficient management and breeding systems for improving coloration and thus marketability. Here, we compared the changes in expression of the six genes involved in the anthocyanin biosynthesis pathway during fruit development of the white peach 'Mochizuki', the red peach 'Akatsuki', and the deep-red 'Flavortop' nectarine.

\section{Materials and Methods}

Plant materials. 'Mochizuki' and 'Akatsuki' peaches and 'Flavortop' nectarine, which were cultivated at the National Institute of Fruit Tree Science (Tsukuba, Ibaraki, Japan), were used as study materials. 'Mochizuki' is a white-skinned cultivar of peach, 'Akatsuki' is a red-skinned cultivar of peach, and 'Flavortop' is a deep-red cultivar of nectarine.

Diameters along the equator of three fruit of each cultivar were measured with calipers on the tree at intervals of 3 to 8 d. Fruit were sampled at three developmental stages in 2002: 1) pre-endocarp-hardening stage, with rapid development and increase in pericarp size; 2) endocarp-hardening stage, with delayed size increase in the mesocarp; 3 ) mature fruit stage, with a rapid increase in mesocarp size (Tukey, 1933). Corresponding to these developmental stages, we set three sampling stages: Stage I, 49 DAFB (days after full bloom) ('Mochizuki' and 'Akatsuki') or 51 DAFB ('Flavortop'); Stage II, 81 DAFB ('Mochizuki' and 'Akatsuki') or 83 DAFB ('Flavortop'); and Stage III, 129 DAFB ('Mochizuki'), 122 DAFB ('Akatsuki'), or 132 DAFB ('Flavortop'). We sampled flowers of the three cultivars at the time of full bloom and fruit at the above three stages for RNA extraction, anthocyanin concentration, and coloration analysis. After sampling, flowers and fruit skins were immediately frozen in liquid nitrogen and kept at $-80^{\circ} \mathrm{C}$ until preparation for RNA or anthocyanin extraction.

Very occasionally, fruit of 'Mochizuki' had red pigment in their skins. These fruit were collected at Stage III, and the red parts of the skin were used for comparison with the normal white 
skins. The coloration of the red parts of the skin was assessed only with a chromometer (as described below), because, unlike in the other peaches and the nectarine, there was not enough red skin to do the more complex analyses.

DETERMINATION OF ANTHOCYANIN CONCENTRATION AND COLORATION IN SKIN. Anthocyanin was extracted from $0.2 \mathrm{~g}$ of flowers (with calyces) or $1 \mathrm{~g}$ of fruit skins. We used $5 \mathrm{~mL}$ of $\mathrm{HCl} / \mathrm{MeOH}$ $1: 49(\mathrm{v} / \mathrm{v})$ in a slight modification of the method of Sun and Francis (1967). The extracts were diluted with the same volume of $\mathrm{HCl} / \mathrm{MeOH} 1: 49(\mathrm{v} / \mathrm{v})$ and then the absorbance reading at a wavelength of $530 \mathrm{~nm}$, as indicative of anthocyanin concentration, was determined with a spectrophotometer (UV-1600; Shimadzu, Kyoto, Japan) in five replicates for each cultivar. Skin color was measured with a portable chromometer (CM-2002; Minolta, Osaka, Japan), and the fruit chromaticity was given an $\mathrm{a}^{*}$ value as an indicator of redness. This $\mathrm{a}^{*}$ value, based on spectrophotometric colorimetry, indicates a range from red to green (Voss, 1992) and is a useful fruit maturity index (Li et al., 2002; McGuire, 1992).

CONSTRUCTION OF PRIMERS AND CLONING OF ANTHOCYANIN BIOSYNTHESIS GENES AND SEQUENCE ANALYSIS. Degenerate primers for the anthocyanin biosynthesis genes were designed from published sequences $\{$ CHS: Dianthus monspessulanus [DNAData Bank of Japan accession no. AF267173], Equisetum arvense (AB030004), Hydrangea macrophylla (AB011467), Malus sp. (X68977), Persea americana (AD001672), Petunia $\times$ hybrida (AF233638), Vitis vinifera (AF020709); CHI: Arabidopsis thaliana (M86358), Petunia $\times$ hybrida (X14589), Zea mays (Z22760), Dianthus caryophyllus (Z67989); F3H: Daucus carota (AF184270), Juglans nigna (AJ278457), Malus $\times$ domestica (AF117270), Vitis vinifera (X75965); DFR: Ipomoea batatas (AB019243), Malus $\times$ domestica (AF117268), Petunia $\times$ hybrida (AF233639); ANS: Daucus carota (AF184274), Vitis vinifera (X75966); UFGT: Forsythia xintermedia (AF127218), Vitis vinifera (X75968), Scutellaria baicalensis (AB031274)\}.

Total RNA was isolated from mature skin of 'Akatsuki' by the CTAB (cetyltrimethylammonium bromide) method described by Kotoda et al. (2000). First-strand cDNA was synthesized from total RNA from the mature skin of 'Akatsuki' by using oligo (dT) primer (cDNA Synthesis System Plus kit; Amersham Pharmacia, Little Chalfont, U.K.). This was amplified under the following conditions by using degenerate primers. $p P p C H S$ was amplified with AmpliTaq Gold (PEApplied Biosystems, Foster City, Calif.): after preheating of the sample at $95^{\circ} \mathrm{C}$ for $12 \mathrm{~min}$, a reaction cycle of $94^{\circ} \mathrm{C}$ for $45 \mathrm{~s}, 50{ }^{\circ} \mathrm{C}$ for $45 \mathrm{~s}$, and $72{ }^{\circ} \mathrm{C}$ for $90 \mathrm{~s}$ was repeated 35 times, followed by $72{ }^{\circ} \mathrm{C}$ for $10 \mathrm{~min}$. $p P p C H I$ and $p P p U F G T$ were amplified by using Ex-Taq (TaKaRa, Otsu, Japan): after preheating of the sample at $95^{\circ} \mathrm{C}$ for $3 \mathrm{~min}$, a reaction cycle of $94{ }^{\circ} \mathrm{C}$ for $30 \mathrm{~s}, 50{ }^{\circ} \mathrm{C}$ for $30 \mathrm{~s}$, and $72{ }^{\circ} \mathrm{C}$ for $60 \mathrm{~s}$ was repeated 35 times, followed by $72^{\circ} \mathrm{C}$ for $10 \mathrm{~min}$. $p P p F 3 H, p P p D F R$, and pPpANS were amplified with Z-Taq (TaKaRa): after preheating of the sample at $95^{\circ} \mathrm{C}$ for $5 \mathrm{~min}$, a reaction cycle of $95^{\circ} \mathrm{C}$ for $10 \mathrm{~s}, 50{ }^{\circ} \mathrm{C}$ for $10 \mathrm{~s}$, and $72^{\circ} \mathrm{C}$ for $20 \mathrm{~s}$ was repeated 35 times, followed by $72{ }^{\circ} \mathrm{C}$ for $10 \mathrm{~s}$. Amplified fragments were cloned into pCR2.1 vector by using a TA cloning system (Invitrogen, San Diego, Calif.). The fragments were sequenced with a BigDye terminator cycle sequencing kit (PE Applied Biosystems) and an automated sequencer (model 377; PE Applied Biosystems). The cloned fragments were also PCR DIG-labeled (PCR DIG Probe Synthesis Kit; Roche Diagnostics, Mannheim, Germany) according to the method of Kobayashi et al. (2001) for RNA and DNA blot analyses.
CHS-MF derived from the red parts of the skin of the 'Mochizuki' peach at Stage III and the deep-red skin of 'Flavortop' at Stage I was used for RNA blot analysis.

RNA BLOT ANALYSIS FOR GENES OF THE ANTHOCYANIN BIOSYNTHESIS PATHWAY. To isolate total RNA, $2 \mathrm{~g}$ of flowers or fruit skin at Stage I and 5.6 to $5.8 \mathrm{~g}$ at Stages II and III was extracted by the SDS (sodium dodecyl sulfate) method (Ikoma et al. 1996), and $5 \mu \mathrm{g}$ of each RNA was separated in a $1.16 \%$ agarose gel in the presence of formaldehyde and transferred to a nylon membrane (Hybond N; Amersham Pharmacia). The membrane was prehybridized for more than $3 \mathrm{~h}$ and hybridized for 14 to $16 \mathrm{~h}$ at $50{ }^{\circ} \mathrm{C}$ with each probe in high-SDS buffer containing $7 \%$ SDS, 0.05 M sodium phosphate buffer $(\mathrm{pH} 7.0), 5 \times \mathrm{SSC}, 50 \%$ deionized formamide, $2 \%$ blocking reagent (Roche Diagnostics), and $0.1 \% \mathrm{~N}$-lauroyl sarcosine. The membrane was washed twice for $5 \mathrm{~min}$ in $2 \times \mathrm{SSC}(0.3 \mathrm{M} \mathrm{NaCl}$ and $0.03 \mathrm{~m}$ trisodium citrate, $\mathrm{pH}$ 7.0) containing $0.1 \%$ SDS at room temperature, then washed twice (for $20 \mathrm{~min}$ and $15 \mathrm{~min}$ ) in $0.1 \times \mathrm{SSC}$ containing $0.1 \%$ SDS at $68^{\circ} \mathrm{C}$.

EXTRACTION OF GENOMIC DNA, AND DNA BLOT ANALYSIS FOR GENES OF THE ANTHOCYANIN BIOSYNTHESIS PATHWAY. Genomic DNA was extracted from young leaves of 'Mochizuki', 'Akatsuki', and 'Flavortop' trees by means of a CTAB method: 1) A 2-g sample was ground into a powder in liquid nitrogen by a pestle and mortar, and the powder was put into a $50-\mathrm{mL}$ tube with $20 \mathrm{~mL}$ of isolation buffer (10\% polyethylene glycol, MW $6000 ; 0.35$ M sorbitol; $0.5 \%$ ß-mercaptoethanol). 2) The tube was vigorously shaken and centrifuged at $8000 g_{n}$ at $4{ }^{\circ} \mathrm{C}$ to make a pellet. 3) The pellet was mixed with $10 \mathrm{~mL}$ of lysis buffer $(0.35 \mathrm{M}$ sorbitol; $0.1 \mathrm{M}$ Tris- $\mathrm{HCl}, \mathrm{pH} 8.0 ; 0.5 \%$ ß-mercaptoethanol) in the tube, then $1.2 \mathrm{~mL}$ of $10 \% \mathrm{~N}$-lauroyl sarcosine was added and the sample was incubated for $10 \mathrm{~min}$ at room temperature. 4) We then added $15 \mathrm{~mL}$ of $2 \times \mathrm{CTAB}$ buffer ( $2 \%$ cetyltrimethylammonium bromide; 0.1 м Tris-HCl, pH 8.0; 20 mм EDTA; 1.4 м NaCl; 0.5\% B-mercaptoethanol) to each tube, and the sample was incubated at $65{ }^{\circ} \mathrm{C}$ for $20 \mathrm{~min}$. 5) After the tube had been cooled to room temperature, the sample was divided into two tubes, and $20 \mathrm{~mL}$ of chloroform/isoamylalchol 24:1 (v/v) was added to each tube, which was then vigorously shaken. 6) The tube was centrifuged at $8000 g_{\mathrm{n}}$ at room temperature for $10 \mathrm{~min}$ to make a supernatant. Then $20 \mathrm{~mL}$ of isopropanol was added to the supernatant to make a precipitate of genomic DNA. 8) The genomic DNA was rinsed with $70 \%$ ethanol and dried, and then was eluted with TE buffer (10 mm Tris-HCl; $1 \mathrm{~mm}$ EDTA) at $4{ }^{\circ} \mathrm{C}$.

Genomic DNA was digested overnight with the restriction enzymes HindIII, PstI, or XbaI at $37{ }^{\circ} \mathrm{C}$. The digested genomic DNAs $(5$ or $10 \mu \mathrm{g}$ ) were separated in a $0.8 \%$ agarose gel and transferred to a nylon membrane, as in the RNA blot analysis. Hybridization was carried out for more than $14 \mathrm{~h}$ with PCR DIG-labeled $p P p C H S, p P p D F R$, and $p P p U F G T$ in high-SDS buffer at $42{ }^{\circ} \mathrm{C}$. The membrane was then washed, as in the RNA blot analysis.

\section{Results}

Color CHANGeS AND ANTHOCYANIN CONCENTRATIONS IN SKINS DURING FRUIT DEVELOPMENT. At the Tsukuba site in the study year (2002), fruit growth exhibited a double sigmoidal growth pattern in 'Mochizuki' and 'Akatsuki' peaches and 'Flavortop' nectarine (Fig. 1). Figure 2 shows the absorbance at $530 \mathrm{~nm}$ as the anthocyanin concentration of flowers and fruit skins. Flowers of all three cultivars were pink because of the presence of 


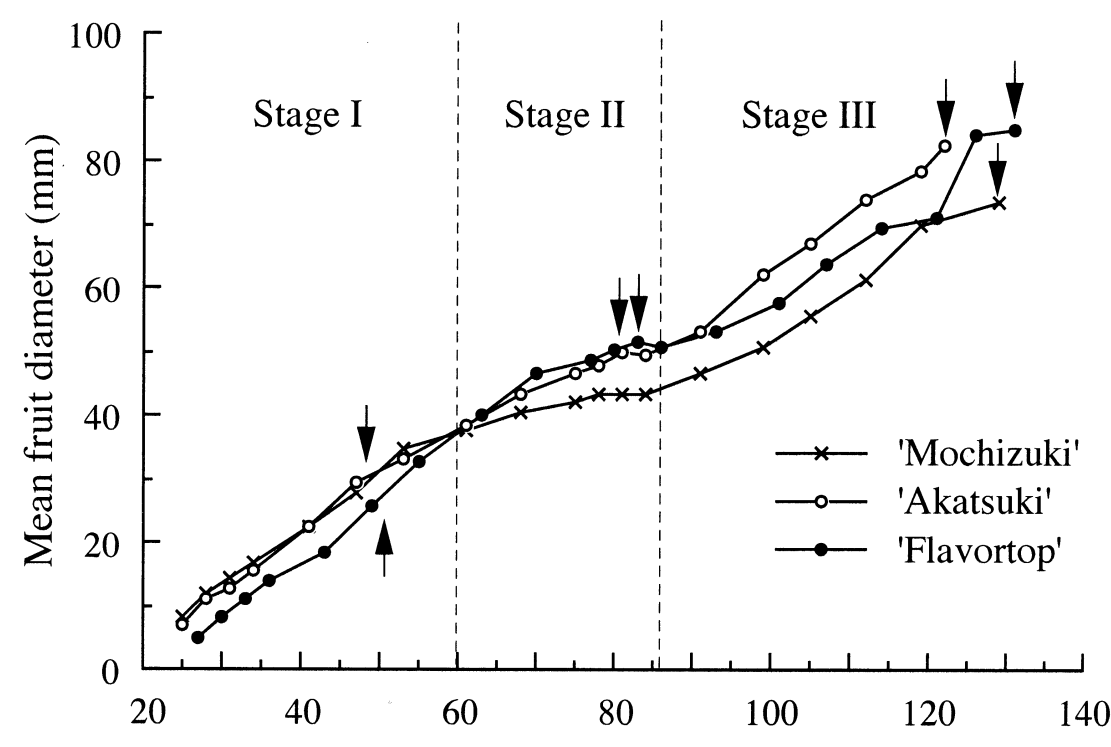

DAFB

Partial fragments of SiX anthocyanin bioSYNTHESIS GENES. Amplified fragments of $\mathrm{CHS}$, $C H I, F 3 H, D F R, A N S$, and UFGT from the skins of mature 'Akatsuki' fruit were deposited in the DNAData Bank of Japan. Their accession numbers are $p P p C H S, \mathrm{AB} 094986 ; p P p C H I, \mathrm{AB} 094987$; pPpF3H, AB097151; pPpDFR, АB095030; pPpANS, AB097216; and pPpUFGT, AB094988, and they are shown with their respective anthocyanin biosynthesis genes in Table 1 . The fragment CHS-MF was amplified with specific primers on the basis of data from $p P p C H S$ and was not deposited in the DNA data bank. Most of the fragments showed the highest homology with corresponding genes in the Rosaceae family.

GENE EXPRESSION IN RNA BLOT ANALYSIS AND COPY NUMBER IN DNA BLOT ANALYSIS. All the anthocyanin biosynthesis genes were clearly expressed in flower and fruit development, with the exception of very low expression of $p P p C H S$ in Stage I of 'Flavortop' nectarine and no expression of $p P p D F R$ in Stage III of the white 'Mochizuki' peach (Fig. 4). Another $C H S$ fragment, $C H S-M F$, from 'Mochizuki' and 'Flavortop', was expressed increasingly in 'Flavortop' from Stage I to Stage III, but in Stage III in 'Mochizuki' it was detected only in the red parts of the skin (Fig. 5). In 'Akatsuki' and 'Flavortop', expression of $p P p C H S$ was lower in Stages I and II than in Stage III (Fig. 4). These changes in transcript levels and anthocyanin accumulation in the skins of 'Akatsuki' and 'Flavortop' were positively related to each other (Figs. 2 and 4). In 'Mochizuki', $p P p C H I, p P p F 3 H, p P p A N S$, and $p P p U F G T$ were expressed in Stage III (Fig. $4)$, even though anthocyanin accumulation was very low (Fig. 2). In Stage III, the transcript for $p P p D F R$ was clearly expressed in the red skin parts of 'Mochizuki', but no expression of $p P p D F R$ in the white skin (Fig. 6).

The CHS, DFR, and UFGT genes showed a number of bands in DNA blot analysis (Fig. 7). In each case this indicated the presence of several copy numbers of the gene, and the patterns of the bands among the three cultivars were the same.

\section{Discussion}

\section{Developmental stage}

Fig. 2. Changes in the anthocyanin concentration (as determined by absorbance at a wavelength of $530 \mathrm{~nm}$ ) of 'Mochizuki' and 'Akatsuki' peaches and 'Flavortop' nectarine in 2002. F: flower at full bloom. I: Stage I, 49 d after full bloom (DAFB) ('Mochizuki' and 'Akatsuki') and 51 DAFB ('Flavortop'); II: Stage II, 81 DAFB ('Mochizuki' and 'Akatsuki') and 83 DAFB ('Flavortop'); III: Stage III, 129 DAFB ('Mochizuki'), 122 DAFB ('Akatsuki'), and 132 DAFB ('Flavortop'). Each value represents the mean of five replications. Vertical bars indicate standard deviations.

accumulated anthocyanin. Anthocyanin concentrations were similar in the skins of 'Akatsuki' peach and 'Flavortop' nectarine and lower in 'Mochizuki' peach, but not remarkably so, except in Stage III.

The anthocyanin concentrations of the fruit skins paralleled the $a^{*}$ values in all three cultivars (Fig. 3 ). In the partly red-skinned 'Mochizuki', the a* value was higher than in the white-skinned specimens. cultivars peaked synchronously at Stages I and III (Fig. 4). In the fruit of red cultivars, anthocyanin absorbance at a wavelength of $530 \mathrm{~nm}$, and the a* values, showed a small peak in Stage I, followed by a large peak in Stage III (Figs. 2 and 3). Thus, in 'Akatsuki' peach and 'Flavortop' nectarine, expression of anthocyanin biosynthesis genes is correlated with fruit color development. In apple fruit, Honda et al. (2002) found that five genes of anthocyanin biosynthesis are coordinately expressed during fruit development and their levels of expression are posi- 


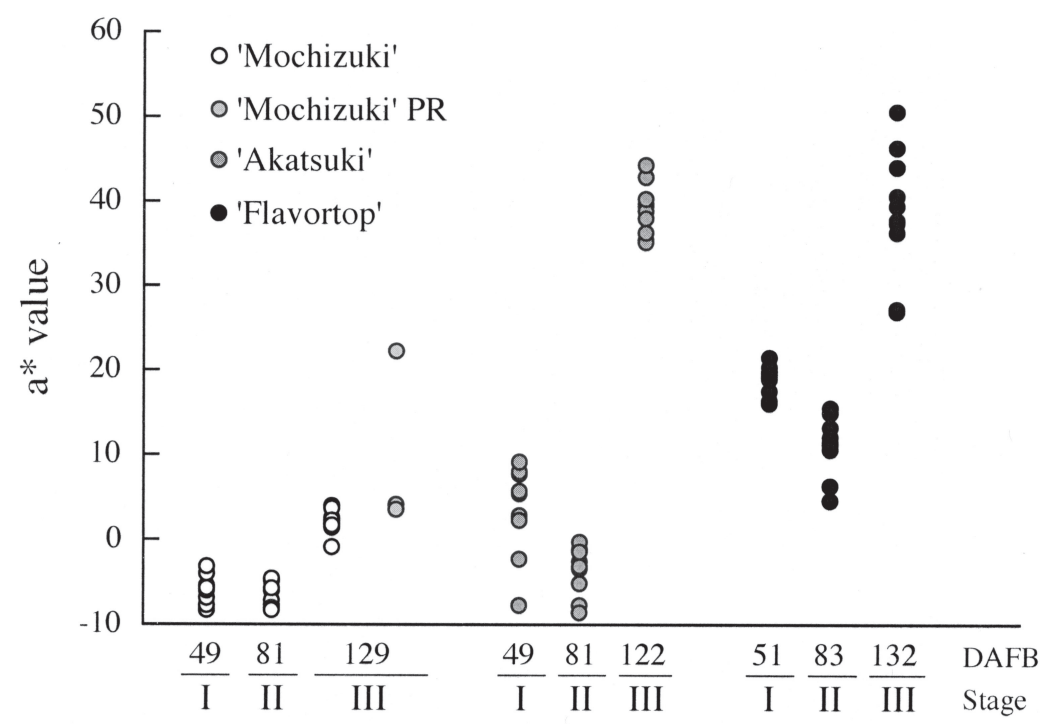

Developmental stage

Fig. 3. Changes in $\mathrm{a}^{*}$ values of skins of white and partly red (PR) 'Mochizuki' peach, and skins of 'Akatsuki' peach and 'Flavortop' nectarine in 2002. I: Stage I, 49 d after full bloom (DAFB) ('Mochizuki' and 'Akatsuki') and 51 DAFB ('Flavortop'); II: Stage II, 81 DAFB ('Mochizuki' and 'Akatsuki') and 83 DAFB ('Flavortop'); III: Stage III, 129 DAFB ('Mochizuki'), 122 DAFB ('Akatsuki'), and 132 DAFB ('Flavortop'). Each column is represented by measurements of 10 fruit, with the exception of the column of the partly red skin of 'Mochizuki' peach, for which there were only three fruit.

tively related to the degree of anthocyanin concentration. Kondo et al. (2002) reported two peaks in expression of the anthocyanin biosynthesis genes. In strawberry fruit, the transcription of DFR shows two peaks during color development, and the gene is considered to have a main role in anthocyanin biosynthesis $(\mathrm{Li}$ et al., 2001; Moyano et al., 1998). In our study, the expression of anthocyanin biosynthesis genes showed two peaks in relation to the pattern of anthocyanin accumulation. This pattern may be common to red fruit of the Rosaceae family, including peach and nectarine. DNAblotting showed the presence of anthocyanin biosynthesis genes as indicators of possible anthocyanin production in all three cultivars (Fig. 7). $C H S-M F$ was isolated from the red skin parts of 'Mochizuki' in Stage III and from 'Flavortop' at all three stages of fruit development (Fig. 5), but pPpCHS expression was very low in 'Flavortop' at Stage I (Fig. 4). These results suggest that $p P p C H S$ is a fragment of the CHS gene and may not be important in anthocyanin production in 'Flavortop' in Stage I, despite the fact that the skin of 'Flavortop' is fully red in Stage I. In contrast, expression of $p P p C H S$ or $C H S-M F$ was not detected in the white skin of 'Mochizuki' peach, even though it was expressed in the red skin parts. This result indicates that $p P p C H S$ may not act in anthocyanin production in mature whiteskinned 'Mochizuki' fruit. 'Mochizuki' was released in 1997 by the National Institute of Fruit Tree Science as a canning peach cultivar without red pigment in its flesh and skin, but with a pink flower (Yamaguchi et al., 2001). In 'Mochizuki', all anthocyanin biosynthesis genes were expressed at Stage II in the presence of less coloration than in the other cultivars (Figs. 2 and 4). Therefore, 'Mochizuki' can be viewed as having a phenotypically white fruit with the capacity for anthocyanin production. In grape, Boss et al. (1996a) reported that samples without anthocyanins expressed all major anthocyanin biosynthesis genes except $U F G T$, and they suggested that these genes were associated with the other biosynthesis pathways, notably those involved in the biosynthesis of aurones, flavones, flavonols, isoflavonoids, and proanthocyanidins. Several genes of the anthocyanin biosynthesis pathway in peach and nectarine skins are likely related to these other pathways, because phenolic compounds such as catechin and epicatechin, which are present in peach (Cheng and Crisosto, 1995), are synthesized by the procyanidin biosynthesis pathway (Porter, 1994).

In grapes, UFGT is a key regulatory gene of anthocyanin biosynthesis (Boss, 1996a; Kobayashi et al., 2001). Moreover, Kobayashi et al. (2002) reported that regulatory MybA gene was involved in the regulation of anthocyanin biosynthesis via UFGT gene expression. Gollop et al. (2002) suggested that, in grape, a specific sequence located between positions -725 and -233 in the $D F R$ promoter might be involved in the expression of the DFR gene. In our study, $p P p C H S / C H S-M F$ and $p P p D F R$ were clearly expressed in the red skin parts of 'Mochizuki' peach, but were not detected in the white skin parts at Stage III (Figs. 4 and 6). These specific expression patterns might be related to differences in function in each gene family or the presence of specific promoter sites. In the white skin parts of 'Mochizuki',

Table 1. List of DNA fragments isolated from peach and nectarine cultivars, with their putative anthocyanin biosynthesis genes.

\begin{tabular}{|c|c|c|c|c|c|c|c|}
\hline \multirow{2}{*}{$\begin{array}{l}\text { Partial fragments } \\
(\mathrm{DDBJ} \text { accession no. })^{\mathrm{z}} \\
p P p C H S \quad(\mathrm{AB} 094986)\end{array}$} & \multirow{2}{*}{$\begin{array}{c}\text { Primer sequences }\left(5^{\prime}-3^{\prime}\right) \\
\text { for RT-PCRy } \\
\text { F: caRggBtgcttYgcHggNggVac }\end{array}$} & \multirow{2}{*}{$\begin{array}{l}\text { Size } \\
\text { (bp) } \\
449\end{array}$} & \multirow{2}{*}{$\begin{array}{c}\begin{array}{c}\text { Putatively } \\
\text { identified gene }\end{array} \\
C H S\end{array}$} & \multirow{2}{*}{$\begin{array}{c}\begin{array}{c}\text { Isolated } \\
\text { from }\end{array} \\
\text { Akatsuki }\end{array}$} & \multicolumn{2}{|c|}{$\begin{array}{c}\text { Homologous to } \\
\text { (DDBJ accession no.) }\end{array}$} & \multirow{2}{*}{$\begin{array}{c}\begin{array}{c}\text { Homology } \\
(\%)\end{array} \\
85.3\end{array}$} \\
\hline & & & & & Rubus idaeus & (AF400566) & \\
\hline & R: tcHaRRatNgcNggSccDccNgg & & & & Malus $\times$ domestica & $(\mathrm{AB} 074485)$ & 84.4 \\
\hline$C H S-M F$ & F: cagggttgctttgccggtgg & 356 & $\mathrm{CHS}$ & Mochizuki & & & \\
\hline & R: tcgatgttcttcgaaataa & & & Flavortop & & & \\
\hline \multirow[t]{2}{*}{ pPpCHI (АВ094987) } & F: ttYacBgYSatHgSHgtVta & 209 & $\mathrm{CHI}$ & Akatsuki & Malus $\times$ domestica & (AF494398) & 85.3 \\
\hline & R: gcMacRcaRttYtcYRYHacYtt & & & & Citrus sinensis & (AB011794) & 78.9 \\
\hline \multirow[t]{2}{*}{$p P p F 3 H \quad(\mathrm{AB} 097151)$} & F: gaRMgDccHaaRgtBgcYtaYaa & 809 & $F 3 H$ & Akatsuki & Malus $\times$ domestica & $(\mathrm{AB} 074486)$ & 90.4 \\
\hline & R: gggttYtggaaNgtKgcDatKga & & & & Pyrus communis & (AF497633) & 90.0 \\
\hline \multirow[t]{2}{*}{$p P p D F R \quad(\mathrm{AB} 095030)$} & F: ttYatYggctcYtggYtNgtcatg & 657 & $D F R$ & Akatsuki & Malus $\times$ domestica & (AF117268) & 87.5 \\
\hline & R: agRtcRtccaRRtgMacataYtg & & & & Vitis vinifera & (Y11749) & 77.5 \\
\hline \multirow[t]{2}{*}{$p P p A N S \quad(\mathrm{AB} 097216)$} & F: gatgaaggScctcaggtKccMac & 822 & ANS & Akatsuki & Malus $\times$ domestica & $(\mathrm{AF} 117269)$ & 91.7 \\
\hline & R: cttYagRatgatcttctcYttMgg & & & & $\begin{array}{c}\text { Vitis labrusca } \times \\
\text { Vitis vinifera }\end{array}$ & $(\mathrm{AB} 073018)$ & 81.4 \\
\hline \multirow[t]{2}{*}{ pPpUFGT (AB094988) } & F: aaYWSYttYgaRgaRMtBga & 482 & $U F G T$ & Akatsuki & Vitis vinifera & (AB047094) & 72.1 \\
\hline & R: ttccaYccacaatgHgtYaYaaa & & & & & & \\
\hline
\end{tabular}

${ }^{\mathrm{zDDBJ}}=$ DNA Data Bank of Japan

$y R=a / g, M=a / c, S=c / g, Y=c / t, W=a / t, K=g / t, D=a / g / t, V=a / c / g, H=a / c / t, B=c / g / t, N=a / c / g / t$. 


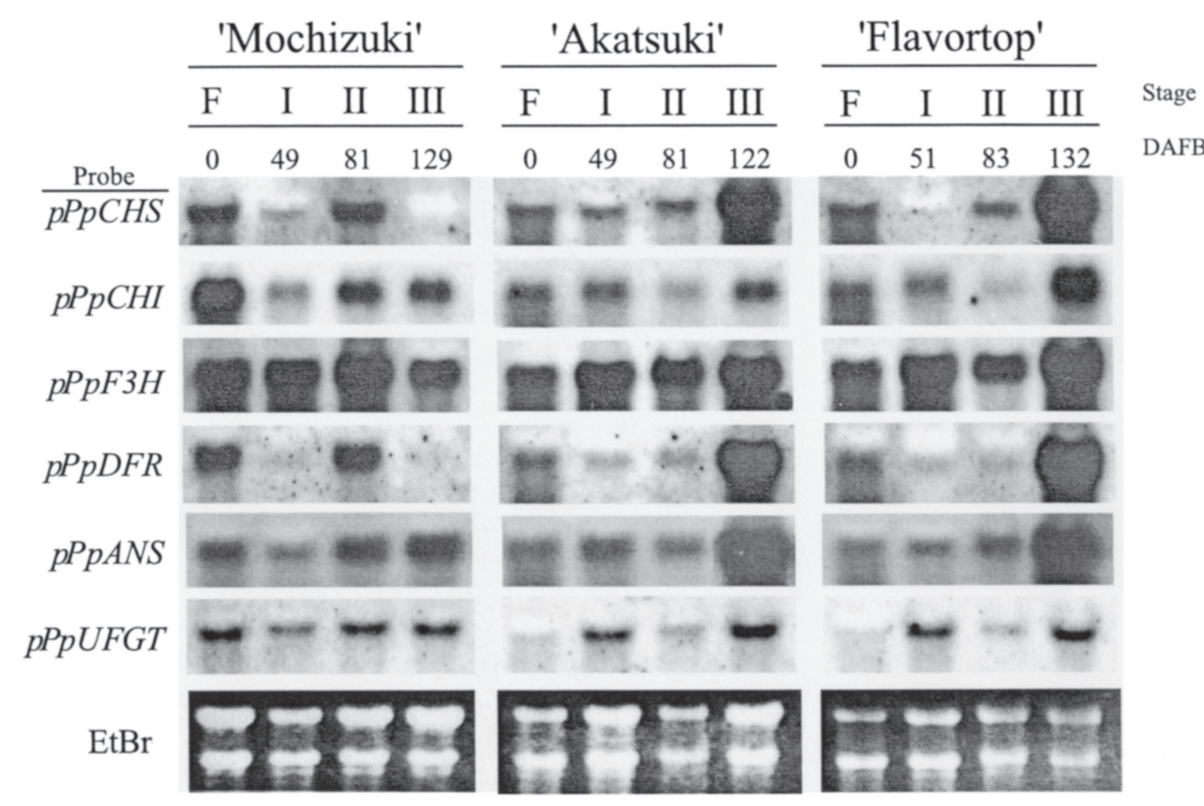

Fig. 4. RNA blot analyses of 'Mochizuki' and 'Akatsuki' peaches and 'Flavortop' nectarine in the flower and fruit developmental stages. Fruit developmental stages are as described in Fig. 3. Total RNAs (5 $\mu \mathrm{g})$ were hybridized with $p P p C H S, p P p C H I, p P p F 3 H, p P p D F R, p P p A N S$, and $p P p U F G T$ probes. Bottom panel shows ethidium-bromide-stained gel as a loading control.

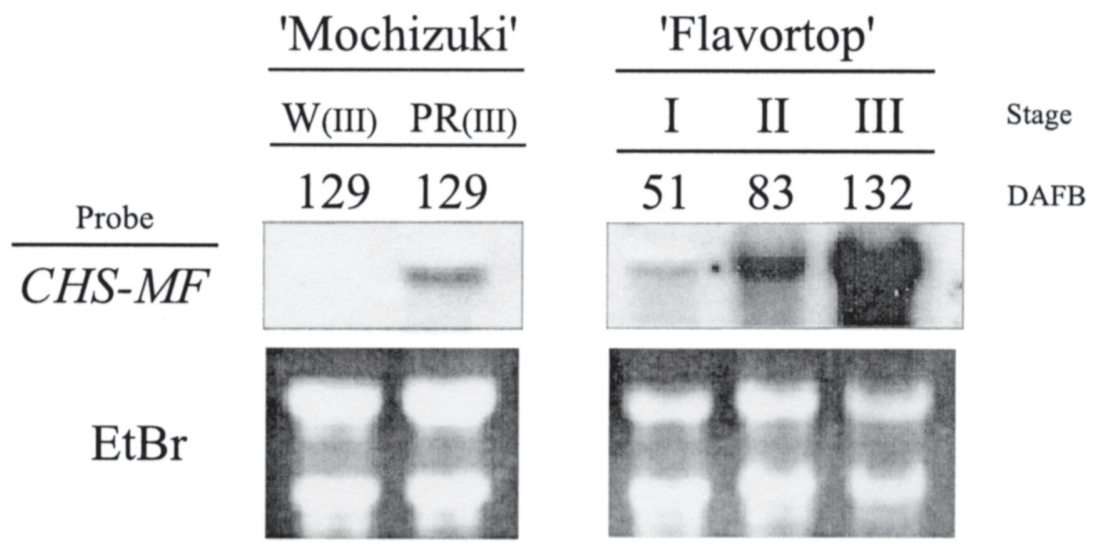

Fig. 5. Expression of CHS-MF in the white (W) and partly red (PR) skin of 'Mochizuki' peach at $129 \mathrm{~d}$ after full bloom (DAFB) in Stage III, and in skin of 'Flavortop' at 51 DAFB in Stage I, 83 DAFB in Stage II, and 132 DAFB in Stage III. Hybridizations for total RNAs (5 $\mu \mathrm{g})$ were as in Fig. 4. Bottom panel shows ethidium-bromide-stained gel as a loading control.

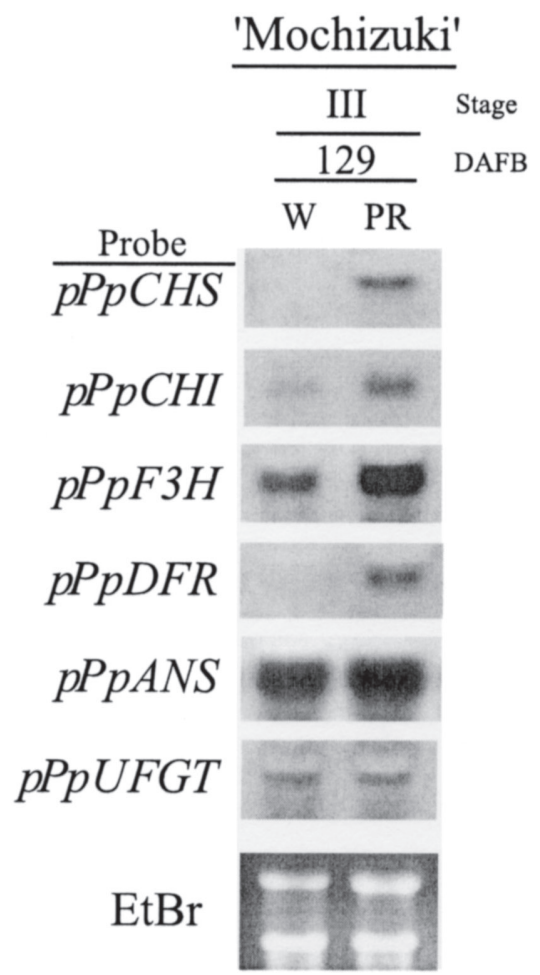

Fig. 6. Expression of anthocyanin biosynthesis genes in the white $(\mathrm{W})$ and partly red (PR) skin of 'Mochizuki' peach at $129 \mathrm{~d}$ after full bloom (DAFB) in Stage III. Hybridizations for total RNAs $(5 \mu \mathrm{g})$ were as in Fig 4 . Bottom panel shows ethidium-bromide-stained gel as a loading control. anthocyanin accumulation was slight, although all of the anthocyanin biosynthesis genes were clearly expressed in Stage II. In the red skin parts of this cultivar, anthocyanin biosynthesis may be controlled by $C H S$ and $D F R$. In all three cultivars, the flowers were pink owing to accumulation of anthocyanins; $p P p C H S, p P p$ $C H I, p P p F 3 H$ showed similar expression levels, and $p P p U F G T$ expression seem more pronounced in the flowers of 'Mochizuki' than in the others (Fig. 4). However, 'Mochizuki' also exhibited the lowest concentration of anthocyanin in flowers. Thus, UFGT might not be a key regulatory gene for anthocyanin biosynthesis in the flowers of peach or nectarine. However, expression of some of the anthocyanin biosynthesis genes $-p P p C H S, p P p F 3 H$, and $p P p D F R$ - was related to anthocyanin accumulation in the skins of the red peach and nectarine, or in the red skin parts of the white peach (Figs. 4 and 6). The copy numbers of the structural genes $p P p C H S, p P p D F R$, and $p P p U F G T$ showed almost the same pattern in all three cultivars (Fig. 7). The cDNA fragments encoding these enzymes could be useful for the determination or comparison of gene expression in peach and nectarine.

Expression of the anthocyanin biosynthesis genes cloned in this study increased in the red skin of peach and nectarine at the mature fruit stage. In particular, $p P p C H S$ and $p P p D F R$ expression showed a dramatic rise in mature fruit of red cultivars with an increase in anthocyanin concentration. In contrast, this rise in $p P p C H S$ and $p P p D F R$ was not evident in the mature white 'Mochizuki' peach (Fig. 4), although all six genes were expressed in the red skin parts of 'Mochizuki', albeit more weakly than in the two red cultivars. These data suggest that $C H S$ and $D F R$ are the key regulatory genes in the process of anthocyanin biosynthesis in mature red peach and nectarine. 

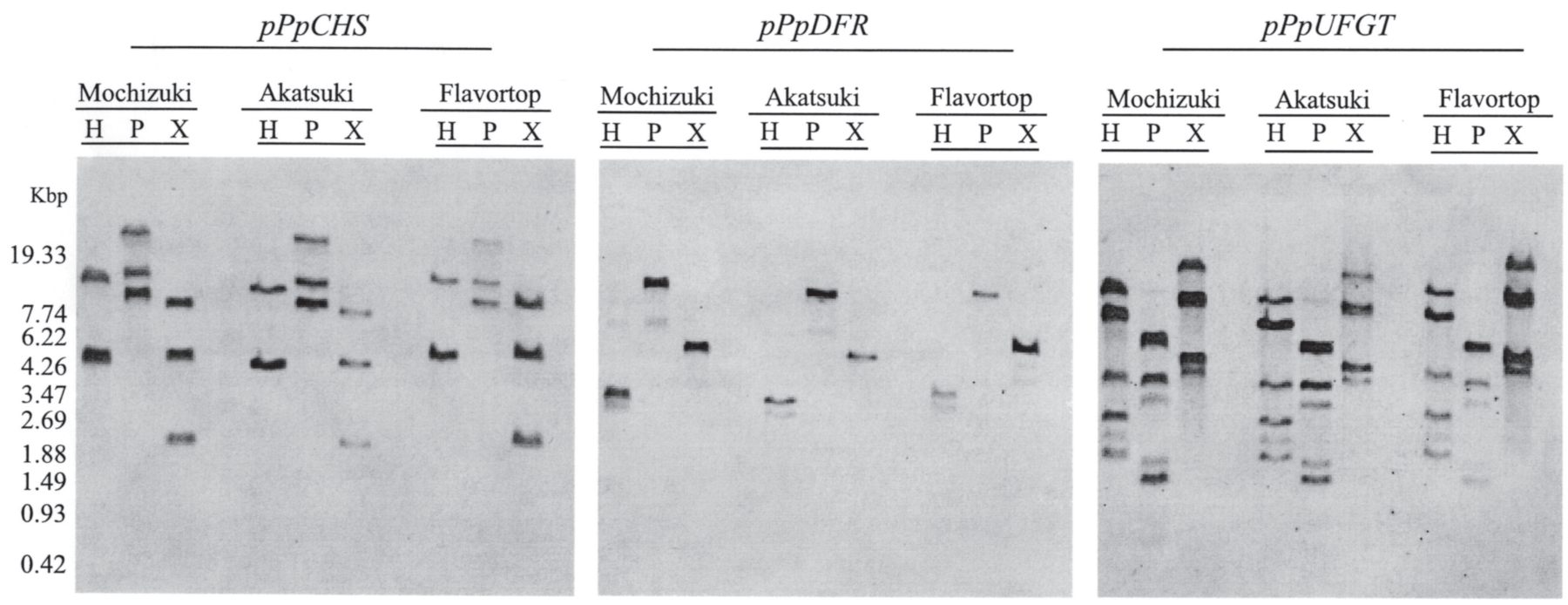

Fig. 7. DNA blot analysis of genomic DNA from young leaves of 'Mochizuki' and ‘Akatsuki' peaches and 'Flavortop' nectarine. DNAs digested with HindIII (H), $P s t \mathrm{I}(\mathrm{P})$, and $\mathrm{Xba \textrm {I }}(\mathrm{X})$ were separated by electrophoresis and transferred to a nylon membrane. The membrane was hybridized with probes of cDNA clones for $p P p C H S, p P p D F R$, and $p P p U F G T$.

\section{Literature Cited}

Boss, P.K., C. Davies, and S.P. Robinson. 1996a. Analysis of the expression of anthocyanin pathway genes in developing Vitis vinifera L. cv Shiraz grape berries and the implications for pathway regulation. Plant Physiol. 111:1059-1066.

Boss, P.K., C. Davies, and S.P. Robinson. 1996b. Expression of anthocyanin biosynthesis pathway genes in red and white grapes. Plant Mol. Biol. 32:565-569.

Cheng, G.W. and C.H. Crisosto. 1995. Browning potential, phenolic composition, and polyphenoloxidase activity of buffer extracts of peach and nectarine skin tissue. J. Amer. Soc. Hort. Sci. 120:835-838.

Gollop, R., S. Even, V. Colova-Tsolova, and A. Perl. 2002. Expression of the grape dihydroflavonol reductase gene and analysis of its promoter region. J. Expt. Bot. 53:1397-1409.

Gross, J. 1987. Pigments in fruit (Food Science and Technology: A series of monographs). Academic, London.

Holton, T.A. and E.C. Cornish. 1995. Genetics and biochemistry of anthocyanin biosynthesis. Plant Cell 7:1071-1083.

Honda, C., N. Kotoda, M. Wada, S. Kondo, S. Kobayashi, J. Soejima, Z. Zhang, T. Tsuda, and T. Moriguchi. 2002. Anthocyanin biosynthetic genes are coordinately expressed during red coloration in apple skin. Plant Physiol. Biochem. 40:955-962.

Ikoma,Y., M. Yano, K. Ogawa, T. Yoshioka, Z.C. Xu, S. Hisada, M. Omura, and T. Moriguchi. 1996. Isolation and evaluation of RNA from polysaccharide-rich tissues in fruit for quality by cDNA library construction and RT-PCR. J. Jpn. Soc. Hort. Sci. 64:809-814.

Kobayashi, S., M. Ishimaru, C.K. Ding, H. Yakushiji, and N. Goto. 2001. Comparison of UDP-glucose:flavonoid 3-O-glucosyltransferase (UFGT) gene sequences between white grapes (Vitis vinifera) and their sports with red skin. Plant Sci. 160:543-550.

Kobayashi, S., M. Ishimaru, K. Hiraoka, and C. Honda. 2002. Myb-related genes of the Kyoho grape (Vitis labruscana) regulate anthocyanin biosynthesis. Planta 215:924-933.
Kondo, S., K. Hiraoka, S. Kobayashi, C. Honda, and N. Terahara. 2002. Changes in the expression of anthocyanin biosynthetic genes during apple development. J. Amer. Soc. Hort. Sci. 127:971-976.

Kotoda, N., M. Wada, S. Komori, S. Kidou, K. Abe, T. Masuda, and J. Soejima. 2000. Expression pattern of homologues of floral meristem identity genes $L F Y$ and $A P 1$ during flower development in apple. J. Amer. Soc. Hort. Sci. 125:398-403.

Li, Y., R. Sakiyama, H. Maruyama, and S. Kawabata. 2001. Regulation of anthocyanin biosynthesis during fruit development in 'Nyoho' strawberry. J. Jpn. Soc. Hort. Sci. 70:28-32.

Li, Z., S. Sugaya, H. Gemma, and S. Iwahori. 2002. Flavonoid biosynthesis and accumulation and related enzyme activities in the skin of 'Fuji' and 'Oorin' apples during their development. J. Jpn. Soc. Hort. Sci. 71:317-321.

McGuire, R.G. 1992. Reporting of objective color measurements. HortScience 27:1254-1255.

Moyano, E., I. Portero-Robles, N. Medina-Escobar, V. Valpuesta, J. Muñoz-Blanco, and J.L. Caballero. 1998. A fruit-specific putative dihydroflavonol 4-reductase gene is differentially expressed in strawberry during the ripening process. Plant Physiol. 117:711-716.

Porter, L.J. 1994. Flavans and proanthocyanidins: Biosynthesis, p. 52-53. In: J.B. Harborne (ed.). The flavonoids. CRC Press, Boca Raton, Fla.

Sun, B.H. and F.J. Francis. 1967. Apple anthocyanins: Identification of cyanidin-7-arabinoside. J. Food Sci. 32:647-649.

Tukey, H.B. 1933. Growth of the peach embryo in relation to growth of fruit and season of ripening. Proc. Amer. Soc. Hort. Sci. 30:209-218.

Voss, D.H. 1992. Relating colorimeter measurement of plant color to the Royal Horticultural Society Color Chart. HortScience 27:1256-1260. Yamaguchi, M., H. Kyotani, M. Yoshida, T. Haji, K. Nishimura, Y. Nakamura, M. Miyake, H. Yaegaki, K. Tanaka, Y. Ishikawa, T. Kihara, K. Suzuki, H. Fukuda, and T. Asakura. 2001. New canning peach cultivar 'Mochizuki' with white flesh (in Japanese with English summary). Bul. Natl. Inst. Fruit Tree Sci. (Jpn) 35:33-45. 